\title{
Purification of RNA-core Induced Streptolysin S, and Isolation and Haemolytic Characteristics of the Carrier-free Toxin
}

\author{
By CATHERINE LORIDAN† AND JOSEPH E. ALOUF* \\ Unité des Antigènes Bactériens (UA CNRS 040557), Institut Pasteur, 28 rue du Docteur Roux, \\ 75724 Paris Cedex 15, France
}

(Received 2 September 1985)

\begin{abstract}
RNA-core (RNAase-resistant fraction of yeast RNA) induced streptolysin S (SLS) was purified $(40 \%$ recovery) to apparent electrophoretic homogeneity by hydroxylapatite chromatography followed by gel filtration on Sephadex G-100 in the presence of $6 \mathrm{M}$-guanidine. $\mathrm{HCl}$. The specific activity of the purified toxin was $3 \times 10^{6}$ haemolytic units (mg protein) $)^{-1}$. The $M_{\mathrm{r}}$ of the toxin was below 4000 on the basis of SDS-PAGE and 20000 by gel filtration in guanidine. HCl. Highvoltage isoelectric focusing of the purified toxin allowed the isolation of the carrier-free SLS peptide for the first time. This peptide was basic (pI 9.2) as compared to native SLS (pI 3.6). The native toxin and the peptide had similar haemolytic properties except for the high lability of the peptide, which was stabilized by RNA-core. The $M_{\mathrm{r}}$ of the denatured peptide was about 1800 , as estimated by gel filtration.
\end{abstract}

\section{INTRODUCTION}

Two haemolytic and cytolytic toxins, streptolysin O (SLO) and streptolysin S (SLS), differentiated by Herbert \& Todd (1944) are produced by group A streptococci (for reviews see Ginsburg, 1970; Alouf, 1980). SLO is a $60 \mathrm{kDa}$ immunogenic protein released in conventional culture media throughout the exponential phase of growth (Dassy \& Alouf, 1983). In contrast, SLS is a less well understood, non-immunogenic toxin which is never detected unless a carrier (also called inducer) is added to the culture or to resting cell suspensions (Bernheimer \& Rodbart, 1948). Many chemically unrelated inducers have been reported, the most potent being RNAaseresistant fraction of yeast RNA (RNA-core) and lipoteichoic acids (see Alouf, 1980; Theodore \& Calandra, 1981). The haemolytic activity can be transferred from one inducer to another (Ginsburg \& Harris, 1963; Taketo \& Taketo, 1964; Koyama, 1964; Calandra \& Oginsky, 1975; Theodore \& Calandra, 1981). This led to the concept that SLS, as first suggested by Bernheimer (1954), is a complex formed by a peptide associated with an inducer, the inducer acting as a carrier or stabilizer. The peptide was estimated to consist of 28 to 32 amino acids (Bernheimer, 1967; Lai et al., 1978). Attempts to isolate a carrier-free haemolytic moiety never succeeded, suggesting that this moiety undergoes decay or denaturation when the complex is treated in ways designed to remove or destroy only the carrier (see Bernheimer, 1972).

The purification, to various extents, of RNA-core induced SLS has been reported (Koyama \& Egami, 1963; Duncan \& Mason, 1976; Hryniewicz et al., 1978; Lai et al., 1978), but no biochemical or immunochemical indications of the homogeneity of the purified preparations were provided, due to the lack of sensitive staining methods and immune sera.

† Present address: Département de Biochimie Médicale, Centre Médical Universitaire, 9 avenue de Champel, 1211 Génève 4, Switzerland.

Abbreviations: BAEE, $N$-benzoylarginine ethyl ester; BHF, basic haemolytic fraction; HU, haemolytic unit; IEF, isoelectric focusing; RNA-core, RNAase-resistant fraction of yeast RNA; SLO, streptolysin O; SLS, streptolysin S; SRBC, sheep red blood cells; TPCK, L-1-tosylamide 2-phenylethyl chloromethyl ketone. 
In addition to erythrocytes, SLS damages and lyses other eukaryotic cells, bacterial protoplasts (see Alouf, 1980) and liposomes composed of various phospholipids (Duncan \& Buckingham, 1981). The lytic effect is inhibited by a variety of phospholipids (Elias et al., 1966), suggesting that these components are involved in the cytolytic action of SLS.

We report in this article the purification to apparent homogeneity of RNA-core induced SLS and the isolation of a haemolytically active carrier-free peptide whose properties are investigated and compared with those of the purified RNA-core-SLS complex.

\section{METHODS}

Chemicals and biochemicals. Hydroxylapatite (Bio-gel HTP) was purchased from Bio-Rad. Trypan Blue, gramicidin D, aprotinin, bovine chain B insulin and RNA-core were from Sigma. Staphylococcal delta-toxin was kindly provided by Dr Monica Thelestam (Karolinska Institute, Stockholm, Sweden). Carboxypeptidase A (EC 3.4.17.1) (35 $\left.\mathrm{U} \mathrm{mg}^{-1}\right)$, carboxypeptidase B (EC 3.4.17.2) $\left(70 \mathrm{U} \mathrm{mg}^{-1}\right)$ and $\alpha$-chymotrypsin (EC 3.4.21.1) $\left(45 \mathrm{U} \mathrm{mg}^{-1}\right)$ were from Worthington. TPCK-treated trypsin (EC 3.4.21 .4, type XIII) $\left(10^{4}\right.$ BAEE U mg ${ }^{-1}$ ) was from Sigma. Leucine aminopeptidase (EC 3.4.11.1) (100 $\left.\mathrm{U} \mathrm{mg}^{-1}\right)$, proteinase $\mathrm{K}$ (EC 3.4.21.14) (20 mU Anson $\left.\mathrm{mg}^{-1}\right)$ and pronase E (type XIV) $\left(7 \mathrm{U} \mathrm{mg}^{-1}\right)$ were from Merck.

Strain and growth conditions. Streptococcus pyogenes strain C203S group A was kindly supplied by Professor Alan W. Bernheimer, New York University School of Medicine. The lyophilized strain was grown at $37^{\circ} \mathrm{C}$ without shaking in brain heart infusion broth (BHI, Difco) supplemented with $1 \%(\mathrm{w} / \mathrm{v})$ maltose and $2 \%(\mathrm{w} / \mathrm{v})$ sodium bicarbonate (BHI-BM).

Induction of streptolysin $S$. A $50 \mathrm{ml}$ volume of an overnight culture was inoculated in 2.51 BHI-BM and grown for $5 \mathrm{~h}$ at $37^{\circ} \mathrm{C}$. The culture was centrifuged at $12000 \mathrm{~g}$ for $25 \mathrm{~min}$ at $4{ }^{\circ} \mathrm{C}$ and the cell pellet washed in $100 \mathrm{mM}$ potassium phosphate buffer, $\mathrm{pH} 7 \cdot 0$, before resuspension to a final volume of $40 \mathrm{ml}$ in induction phosphate buffer (IB) (100 mM- $\mathrm{KH}_{2} \mathrm{PO}_{4}, 2 \mathrm{~mm}-\mathrm{MgSO}_{4}$; adjusted to $\mathrm{pH} 7.0$ with $\left.\mathrm{NaOH}\right)$ supplemented with $30 \mathrm{~mm}$-maltose. The cell suspension (about $17 \mathrm{mg}$ dry wt cocci $\mathrm{ml}^{-1}$ ) was incubated for $5 \mathrm{~min}$ at $37^{\circ} \mathrm{C}$ and then induced by adding $0.5 \mathrm{mg} \mathrm{RNA}$-core per $\mathrm{ml}$ of suspension $(2.9 \%, \mathrm{w} / \mathrm{w}$, cocci) for $5 \mathrm{~min}$ without shaking. The cell suspension was then immediately centrifuged at $4{ }^{\circ} \mathrm{C}$ at $15000 \mathrm{~g}$ for $20 \mathrm{~min}$. The supernate (crude SLS) was collected and supplemented with ammonium acetate ( $100 \mathrm{~mm}$ final concentration) to stabilize SLS as suggested by Lai et al. (1978). The pellet was then resuspended in $40 \mathrm{ml} \mathrm{IB}$, supplemented with maltose (15 mM final concentration), and induced as described above. Four successive inductions could be made on the same pellet. The combined haemolytic material (about $240 \mathrm{ml}$ ) contained 3-5 $\times 10^{5}$ haemolytic units (HU) of SLS obtained from 2.51 of culture [450-750 HU ( $\mathrm{mg}$ cell dry $\left.\mathrm{wt}^{-1}\right)^{-1}$.

Streptolysin S assay. The lytic effect of SLS on erythrocytes was used for toxin assay. Defibrinated sheep blood (Institut Pasteur Production) was centrifuged $(5000 \mathrm{~g}, 5 \mathrm{~min})$ and the erythrocyte pellet was washed three times in 150 mM-sodium PBS, pH 6.8 (Alouf \& Raynaud, 1968). Sheep red blood cells (SRBC) were suspended (about $2.5 \%, \mathrm{v} / \mathrm{v}$ ) in PBS such that a 30 -fold dilution of this suspension in distilled water gave an $A_{541}$ of 0.200 . This standard SRBC suspension (about $6 \times 10^{8} \mathrm{cells} \mathrm{m}^{-1}$ ) was kept at $4^{\circ} \mathrm{C}$ and used within $5 \mathrm{~d}$.

Volumes of appropriately diluted toxin solution decreasing in $0.1 \mathrm{ml}$ amounts from 1 to $0.1 \mathrm{ml}$ were placed in tubes and the volume in all tubes was brought to $1 \mathrm{ml}$ by adding PBS; then $0.5 \mathrm{ml} \mathrm{SRBC}$ was added. The tubes were incubated at $37^{\circ} \mathrm{C}$ for $45 \mathrm{~min}$ and then briefly centrifuged. The percentage of haemolysis was estimated by the $A_{541}$ of the haemoglobin in the supernatant fluid. One $\mathrm{HU}$ was defined as the amount of test material which caused $50 \%$ lysis of the cells. Values were estimated graphically by plotting on a log probit graph (Alouf \& Raynaud, 1968) the percentage of lysis against the volume of toxin sample. Appropriate controls were set by mixing the test material with cholesterol $\left(10 \mu \mathrm{g} \mathrm{ml}^{-1}\right)$, which inhibits the haemolytic activity of SLO but not that of SLS, or with trypan blue $\left(13 \mu \mathrm{g} \mathrm{ml}^{-1}\right)$, which inhibits SLS. The RNA-core alone used for induction did not exhibit any haemolytic activity up to $10 \mathrm{mg} \mathrm{ml}^{-1}$.

Effect of various compounds on haemolytic activity. Preparations of SLS and BHF (see below) with an initial haemolytic activity of $10 \mathrm{HU}$ were used. The potentially inhibitory compounds were used at the following concentrations (the time of preincubation, if any, with the toxin before adding SRBC is shown in parentheses): bovine serum albumin, $0.5 \%(\mathrm{w} / \mathrm{v})$; sucrose, $0.3 \mathrm{M} ; \mathrm{Ca}^{2+}, 5 \mathrm{mM}$; phosphatidylcholine, $4 \mathrm{mg} \mathrm{ml}^{-1}(10 \mathrm{~min})$; trypan blue, $13 \mu \mathrm{g} \mathrm{ml}^{-1}(10 \mathrm{~min})$; cholesterol, $100 \mu \mathrm{g} \mathrm{ml}^{-1}(10 \mathrm{~min})$; enzymes (see Results; 1 enzyme unit per $\mathrm{HU}$, $2 \mathrm{~min}$ ). Compounds were considered inhibitory if they inhibited lysis by at least $80 \%$.

Protein determination. Protein content was determined by the method of Lowry. Bovine serum albumin was used as a standard.

Slab PAGE. SLS preparations (20-100 $\mu \mathrm{g}$ protein $\mathrm{ml}^{-1}$ ) were analysed by SDS-PAGE according to Laemmli (1970). Toxin samples $(20-50 \mu \mathrm{l})$ containing $1.5 \%(\mathrm{w} / \mathrm{v})$ SDS, $10 \%(\mathrm{v} / \mathrm{v})$ glycerol, and $5 \%(\mathrm{v} / \mathrm{v}) 2$-mercaptoethanol in Tris/glycine buffer were boiled for $90 \mathrm{~s}$ in a water bath before loading onto the gel. The tracking dye $(0.001 \%$ bromothymol blue) was added only to the $M_{\mathrm{r}}$ markers. Electrophoresis was run on a $15 \%(\mathrm{w} / \mathrm{v})$ polyacrylamide 
slab gel (pH 8.9) $(10 \times 14 \mathrm{~cm} ; 0.75 \mathrm{~mm}$ thick) at $2.5 \mathrm{~mA}$ for $15 \mathrm{~h}$ until the dye had migrated to $1 \mathrm{~cm}$ from the lower edge of the plate. Sample wells were made from $3 \%(\mathrm{w} / \mathrm{v})$ acrylamide containing $0.1 \% \mathrm{SDS}$. After electrophoresis the gels were silver stained (Morrissey, 1981).

The same preparations were also analysed by electrophoresis at $4{ }^{\circ} \mathrm{C}$ under non-denaturing conditions, by omitting SDS and 2-mercaptoethanol.

Isoelectric focusing $(I E F)$. This was done with a $110 \mathrm{ml}$ column (LKB) as directed in the LKB manual. A pH 3.511 gradient was generated with two sucrose solutions containing respectively 5 and $15 \%(\mathrm{v} / \mathrm{v})$ carrier ampholytes (LKB Ampholines) and 1.5 and $45 \%(w / v)$ sucrose. The less dense solution contained the toxin sample $(300 \mu \mathrm{l}$, $40000 \mathrm{HU})$. The central electrode solution (anode) consisted of $1 \%(\mathrm{v} / \mathrm{v})$ sulphuric acid and $60 \%(\mathrm{w} / \mathrm{v})$ sucrose. The cathode solution $(0.2 \mathrm{ml}$ ethylenediamine in $10 \mathrm{ml}$ distilled water) was layered on the top of the gradient. A final potential of $1600 \mathrm{~V}$ was applied for $16 \mathrm{~h}$ at $2{ }^{\circ} \mathrm{C}$, then the column contents were collected ( $1 \mathrm{ml}$ fractions) and monitored for $\mathrm{pH}\left(4^{\circ} \mathrm{C}\right), A_{280}$ and haemolytic titre. When specified, IEF under dissociating conditions was run in the presence of $6 \mathrm{M}$-urea dissolved in the sucrose solutions.

Purification of streptolysin $S$. All steps were done at $4{ }^{\circ} \mathrm{C}$. Crude non-dialysed SLS preparation $(240 \mathrm{ml})$ was applied to a column $(2.5 \times 14 \mathrm{~cm})$ of hydroxylapatite that had been equilibrated with $100 \mathrm{~mm}$-potassium

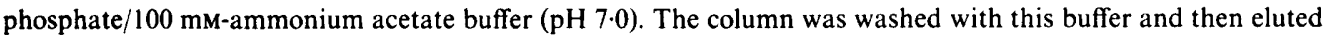

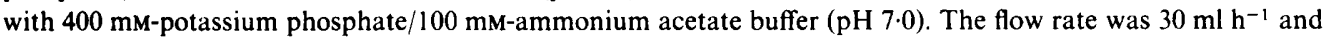
$3 \mathrm{ml}$ fractions were collected and analysed for $A_{280}$ and haemolytic titre. The haemolytically active fractions were pooled (about $30 \mathrm{ml}$ ) and concentrated by ultrafiltration in an Amicon cell fitted with a YM2 membrane ( $M_{\mathrm{r}}$ cutoff 1000). After repeated washing in this cell with $20 \mathrm{~mm}$-potassium phosphate/100 mM-ammonium acetate buffer (pH 7.0), the retentate (fraction F $1,4.5 \mathrm{ml}$ ) was supplemented with $5 \mathrm{ml} 6 \mathrm{M}$-guanidine. $\mathrm{HCl}$ as described by Lai $e t$ al. (1978), allowed to stand at room temperature for $15 \mathrm{~min}$, ice-chilled, loaded onto a Sephadex G-100 column (2.6 $\times 100 \mathrm{~cm}$ ) equilibrated with $20 \mathrm{~mm}$-potassium phosphate $/ 100 \mathrm{~mm}$-ammonium acetate buffer $(\mathrm{pH} 7 \cdot 0)$ and eluted (flow rate $15 \mathrm{ml} \mathrm{h}^{-1}$ ) with this buffer. Eluted fractions $(3.5 \mathrm{ml})$ were monitored as described above. The selected haemolytic pool was concentrated by ultrafiltration (fraction $\mathrm{F} 2,2 \cdot 2 \mathrm{ml}$ ) and stored at $-20^{\circ} \mathrm{C}$.

Amino acid analyses. These were done by the method of Spackman et al. (1958) with a Beckman Multichrom B analyser, using the monocolumn procedure of Devenyi (1969). Samples of purified SLS (10 $\mu \mathrm{g})$ and RNA-core $(10 \mu \mathrm{g})$ were dialysed against water and then hydrolysed for 24,48 or $72 \mathrm{~h}$ at $110^{\circ} \mathrm{C}$ with $6 \mathrm{M}-\mathrm{HCl}$ in sealed Pyrex tubes after evacuation and degassing. The hydrolysates were dried under air before analysis.

Determination of the $M_{r}$ of denatured basic haemolytic fraction $(B H F)$. This fraction $(1 \mathrm{ml}, 1000 \mathrm{HU})$ separated from purified SLS by IEF was boiled for $2 \mathrm{~min}$ in $1.5 \%$ (w/v) SDS and loaded onto a Biogel P6 (Bio-Rad) column $(2.5 \times 40 \mathrm{~cm})$ equilibrated with $20 \mathrm{~mm}$-potassium phosphate $/ 100 \mathrm{mM}$-ammonium acetate buffer $(\mathrm{pH} 7.0)$ and previously calibrated with the following peptides (boiled in $1.5 \% \mathrm{SDS}$ ): aprotinin $(6 \mathrm{kDa})$, staphylococcal deltatoxin $(2.9 \mathrm{kDa})$, bovine chain B insulin $(3.3 \mathrm{kDa})$ and gramicidin $\mathrm{D}(1.7 \mathrm{kDa})$. The BHF sample was eluted with the same buffer (flow rate $50 \mathrm{ml} \mathrm{h}^{-1}$ ) and $1 \mathrm{ml}$ fractions were monitored for $A_{280}$.

\section{RESULTS}

\section{Purification of SLS}

A summary of purification steps is given in Table 1 . The haemolytic activity of the crude material was recovered as a single sharp peak in fractions 160-190 of the hydroxylapatite column (Fig. 1); these fractions were pooled and concentrated. The resulting preparation (fraction $\mathrm{F}$ ), supplemented with guanidine. $\mathrm{HCl}$, was gel-filtered on a Sephadex G-100 column. Two protein peaks were eluted, the first of which coincided with haemolytic activity (Fig. 2). Fractions 80-110 had the highest specific activity. They were pooled and concentrated (fraction F2). The apparent $M_{\mathrm{r}}$ of this pool determined by gel filtration on the calibrated column was about 20000 in the presence of guanidine. $\mathrm{HCl}$ and 40000 in its absence. When submitted to SDS-PAGE and silver staining, fraction F2 ran as a single band (Fig. 3) migrating at the same $R_{F}$ as bromothymol blue, suggesting an apparent $M_{\mathrm{r}}$ below 4000. Fraction F2, which contained $41 \%$ of the haemolytic activity of the initial crude material, was considered to be highly purified SLS. Its specific activity ranged from 1.2 to $3.6 \times 10^{6} \mathrm{HU} \mathrm{mg}^{-1}$ for the various preparations purified.

\section{Characteristics of purified SLS}

When submitted to PAGE in the absence of detergent, fraction F2 revealed a single haemolytic band on the migration front, as shown either by cutting the gel with subsequent elution and titration or by layering it with SRBC (data not shown). Consequently fraction F2 appeared to be a single haemolytic entity negatively charged at $\mathrm{pH} 8.9$. 


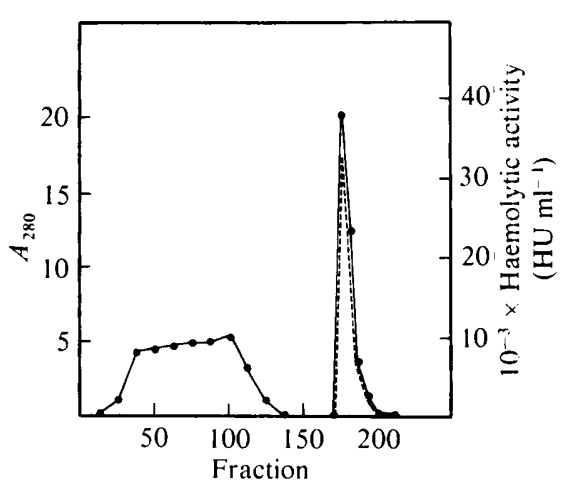

Fig. 1

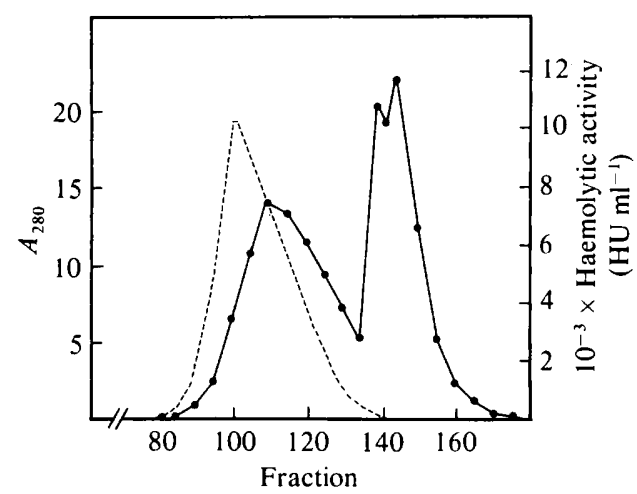

Fig. 2

Fig. 1. Chromatographic separation of crude SLS on a hydroxylapatite column (see Methods). $A_{280} ;----$, haemolytic activity.

Fig. 2. Gel filtration of fraction F1 (Table 1) on a Sephadex G-100 column in 6 M-guanidine. $\mathrm{HCl}$ (see Methods). -,$A_{280} ;--\ldots$, haemolytic activity.

\section{Table I. Purification of $S L S$}

The procedure is fully described in Methods.

\section{Fractionation step}

Starting material

Hydroxylapatite chromatography

(fraction F1)

Gel filtration (fraction F2)

$\begin{array}{cccccc}\begin{array}{c}\text { Volume } \\ (\mathrm{ml})\end{array} & \begin{array}{c}\text { Total } \\ \text { activity } \\ (\mathrm{HU})\end{array} & \begin{array}{c}\text { Total } \\ \text { protein } \\ (\mathrm{mg})\end{array} & \begin{array}{c}\text { Specific } \\ \text { activity } \\ \left(\mathrm{HU} \mathrm{mg}^{-1}\right)\end{array} & \begin{array}{c}\text { Purification } \\ \text { factor }\end{array} & \begin{array}{c}\text { Yield } \\ (\%)\end{array} \\ 240 & 533000 & 12 \cdot 6 & 42300 & 1 & 100 \\ 4 \cdot 5 & 536000 & 0.72 & 745000 & 17.6 & 100 \\ 2 \cdot 2 & 218250 & 0.185 & 1178000 & 27.9 & 41\end{array}$

Table 2. Amino acid composition (nmol) of purified SLS $(10 \mu \mathrm{g})$ and RNA-core $(10 \mu \mathrm{g})$

\begin{tabular}{|c|c|c|c|c|c|}
\hline Amino acid & Purified SLS & RNA-core & Amino acid & Purified SLS & RNA-core \\
\hline Glu or Gln & $5 \cdot 9$ & $4 \cdot 6$ & Tyr & 0.7 & 0.9 \\
\hline Asp or Asn & $5 \cdot 2$ & $4 \cdot 5$ & Phe & 0.85 & 0.8 \\
\hline Gly & $24 \cdot 6$ & $18 \cdot 1$ & Lys & $2 \cdot 4$ & 6.0 \\
\hline Ala & $4 \cdot 2$ & $4 \cdot 6$ & Arg & $1 \cdot 2$ & 0.9 \\
\hline Val & $1 \cdot 7$ & $2 \cdot 2$ & Thr & 1.7 & $2 \cdot 8$ \\
\hline Ile & $0 \cdot 85$ & $1 \cdot 0$ & Ser & $3 \cdot 1$ & $3 \cdot 5$ \\
\hline Leu & $1 \cdot 5$ & 1.5 & Met & 0.7 & $0 \cdot 3$ \\
\hline
\end{tabular}

The amino acid composition of SLS and RNA-core is reported in Table 2. The SLS preparation lacked cysteine, histidine, proline and tryptophan. The data obtained indicated that a protein contaminant was present in the inducer. Whether this contaminant remained associated with RNA-core in the purified toxin awaits further investigation.

\section{IEF of purified SLS}

Purified SLS ( $400 \mu$ l of fraction F2 containing $40000 \mathrm{HU})$ was submitted to IEF in a $3 \cdot 5-$ $11 \mathrm{pH}$ gradient. The toxin preparation was resolved into two sharp haemolytic peaks around pH 3.6 and 9.2 and four non-haemolytic peaks (pI $3.9,4.2,4.5,6.0$ ). Only $25 \%$ of the initial activity applied was recovered. However, toxin titres were very probably underestimated due to inhibitory effects of ampholines and sucrose on erythrocyte lysis.

The acidic haemolytic fraction (about $8000 \mathrm{HU}$ ) was washed and concentrated by ultrafiltration as described for fraction Fl. The retentate (about $2 \mathrm{ml}$ ), when electrofocused in a $3.5-11 \mathrm{pH}$ gradient in the presence of urea, yielded two peaks, of pI 4.95 and 9.7 (Fig. $4 c$ ). Under 


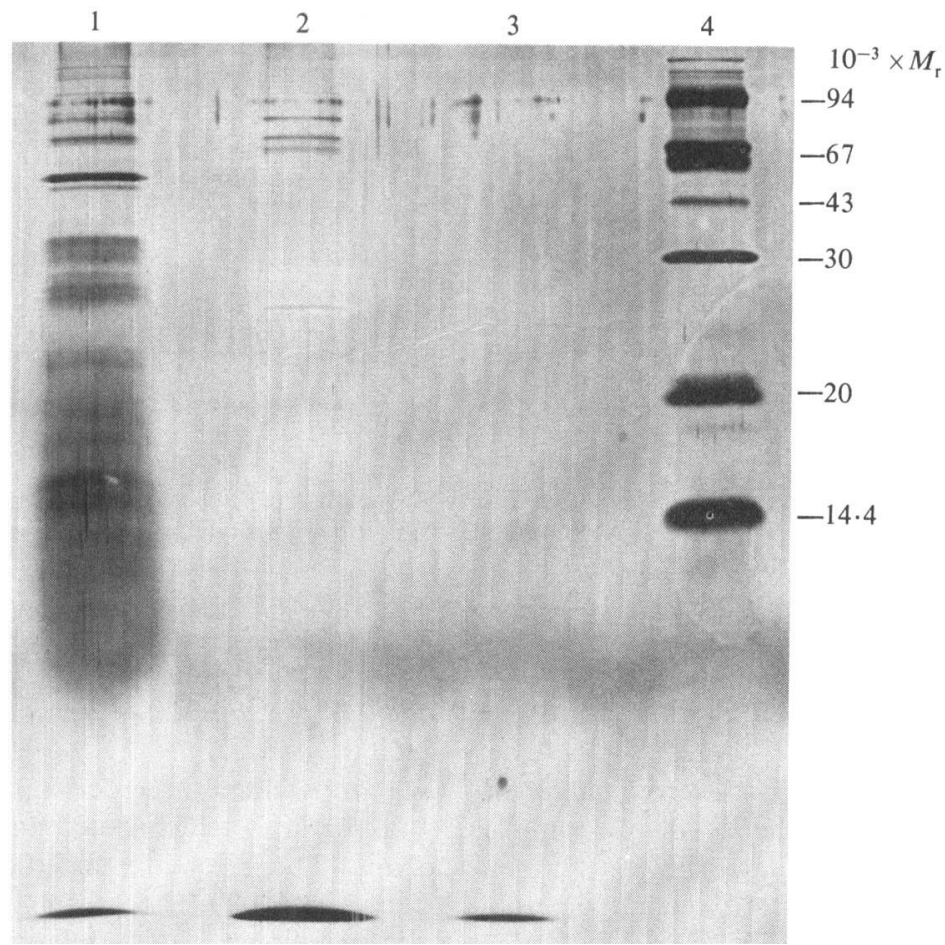

Fig. 3. Slab SDS-PAGE of purification fractions (Table 1). From left to right: (1) starting material, (2) fraction 1, (3) fraction 2 (purified SLS), (4) standard $M_{\mathrm{r}}$ markers.

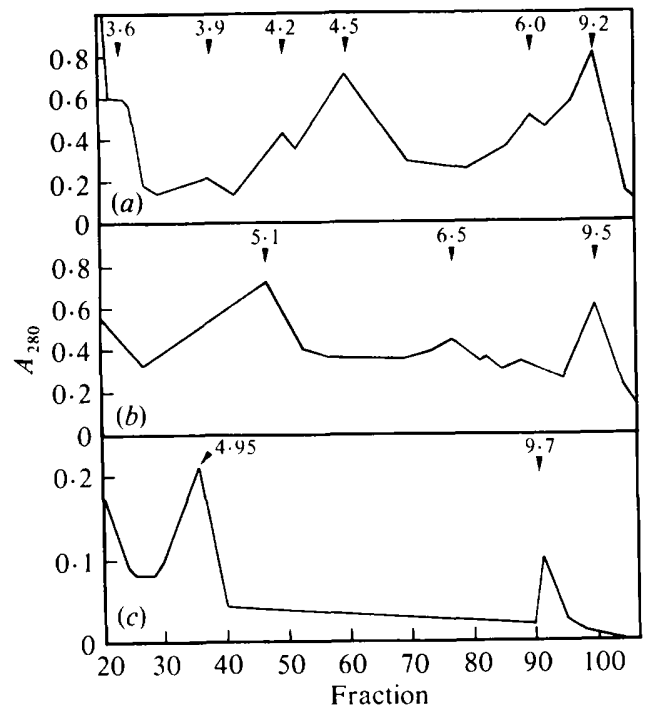

Fig. 4. $(a, b)$ Isoelectric focusing of purified SLS (fraction 2, Table 1) in a sucrose/ampholine pH $3 \cdot 5-$ 11) gradient in the absence $(a)$ or presence $(b)$ of $6 \mathrm{M}$-urea. (c) IEF in $6 \mathrm{M}$-urea of the material of the pI 3.6 peak in $(a)$. The arrows indicate pI values at maximum $A_{280}$ of the resulting peaks. 


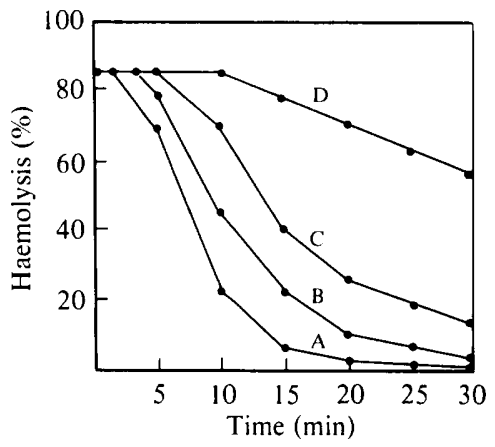

Fig. 5

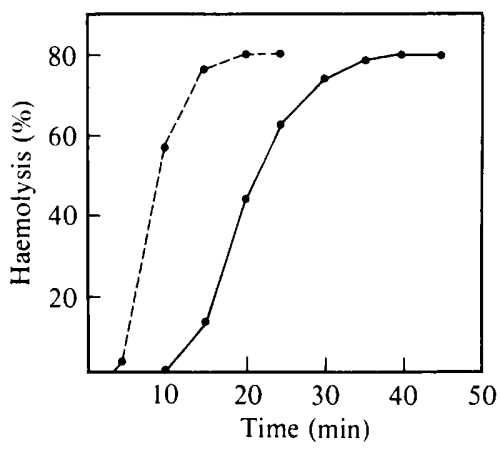

Fig. 6

Fig. 5. Residual haemolytic activity of BHF (carrier-free SLS peptide, $2 \mathrm{HU} \mathrm{m}^{-1}$ ) as a function of incubation time at $37^{\circ} \mathrm{C}$ in PBS (A) and in PBS containing $6 \mu \mathrm{M}$-bovine serum albumin (B), $6 \mu \mathrm{M}$ RNA-core (C) or $20 \mu \mathrm{M}$-RNA-core (D).

Fig. 6. Kinetics of haemoglobin release by SLS (---) and BHF (--). The haemolysins $\left(100 \mu \mathrm{l}, 20 \mathrm{HU} \mathrm{ml}^{-1}\right)$ were added to a series of tubes containing $0.9 \mathrm{ml}$ PBS (pH 6.8) and $0.5 \mathrm{ml}$ of SRBC and incubated at $37^{\circ} \mathrm{C}$. At the times shown the tubes were centrifuged at $4{ }^{\circ} \mathrm{C}(10000 \mathrm{~g}, 5 \mathrm{~min})$ and haemoglobin in the supernate was assayed as described in Methods.

the same dissociating conditions, fractions F2 (Fig. $4 b$ ) yielded three peaks, of pI $5 \cdot 1,6.5$ and 9.5. The haemolytic fraction of $\mathrm{pI}$ around $9 \cdot 2$ (Fig. $4 a$ ) was concentrated and washed in the Amicon cell to eliminate sucrose and ampholytes. The retentate constituting this basic haemolytic fraction (BHF) contained about $5 \%$ (about $2000 \mathrm{HU}$ ) of the total haemolytic material submitted to IEF. SDS-PAGE of BHF did not allow accurate determination of its $M_{\mathrm{r}}$ because it migrated close to the tracking dye. BHF was then denatured and gel-filtered on the calibrated Biogel P6 column (1000-6000 $M_{\mathrm{r}}$ range); it emerged as a single peak of $M_{\mathrm{r}}$ about 1800 (data not shown).

\section{Comparison of the properties of $S L S$ and $B H F$}

The most striking feature of BHF was its high thermal lability as compared to SLS. The halflife (in terms of haemolytic activity) at $37^{\circ} \mathrm{C}$ was about $7 \mathrm{~min}$ for the former (Fig. 5) and $25 \mathrm{~min}$ for the latter. The half-life of $\mathrm{BHF}$ increased fivefold when RNA-core was present during incubation at $37^{\circ} \mathrm{C}$ (Fig. 5). BHF was much more stable at $-20^{\circ} \mathrm{C}$, but even at this temperature, a progressive loss of haemolytic activity occurred within a few weeks. Haemolytic activity was inhibited identically for both SLS and BHF upon incubation with trypan blue or phosphatidylcholine but not with cholesterol or bovine serum albumin. SLS and BHF haemolytic activities were lost after incubation with $\alpha$-chymotrypsin, pronase and proteinase $K$. In contrast, the two haemolysins were insensitive to trypsin, carboxypeptidases $\mathrm{A}$ and $\mathrm{B}$, and leucine aminopeptidase.

The kinetics of the haemolysis of SRBC by SLS and BHF is shown in Fig. 6 . For the same amounts of haemolysins (in terms of $\mathrm{HU}$ ), the lag preceding haemoglobin release and the time required for optimal lysis was twice as high for BHF. The effect of temperature on the lytic process was identical for both SLS and BHF. No lysis took place at $4{ }^{\circ} \mathrm{C}$ even after several hours incubation $\left(2 \mathrm{HU} \mathrm{ml} \mathrm{m}^{-1}\right)$ with SRBC. The behaviour of the two haemolysins was similar as regards the effect of $\mathrm{pH}$ on the lytic process at $37^{\circ} \mathrm{C}$ : lytic activity was maximal at $\mathrm{pH} 6.8$, decreasing rapidly on the acidic side to less than $10 \%$ at $\mathrm{pH} 5 \cdot 5$, and more slowly on the alkaline side up to pH 9.0. The haemolytic activity of SLS and BHF was optimal in 75 mm-sodium phosphate $/ 75 \mathrm{~mm}-\mathrm{NaCl}$ at $\mathrm{pH} 6 \cdot 8$. For both preparations, it decreased at the same $\mathrm{pH}$ by $20 \%$ in $150 \mathrm{~mm}$-sodium phosphate, $60 \%$ in $150 \mathrm{~mm}$-potassium phosphate and $40 \%$ in $19 \mathrm{~mm}$-citric acid/131 mu-sodium phosphate. BHF activity $\left(1.5 \mathrm{HU} \mathrm{ml}^{-1}\right)$ was totally inhibited by $5 \mathrm{~mm}$ $\mathrm{Ca}^{2+}$ and by $70 \%$ by $5 \mathrm{~mm}-\mathrm{Cu}^{2+}$; the inhibition was $80 \%$ and $60 \%$, respectively, for SLS. Neither haemolysin was inhibited by $5 \mathrm{mM}-\mathrm{Zn}^{2+}$ or by $5 \mathrm{mM}-\mathrm{Mg}^{2+}$. Both SLS and BHF were inhibited by $0 \cdot 3 \mathrm{M}$-sucrose. 
DISCUSSION

SLS is unusually labile (Bernheimer, 1983) and its instability through manipulative steps, probably due to its hydrophobicity, has hampered its purification and characterization (Ginsburg, 1970; Lai et al., 1978). No indication as to the molecular homogeneity of purified SLS preparations has been provided by previous investigators and most efforts have been directed toward the isolation of the carrier-haemolysin complex rather than that of the putative haemolytic peptide moiety (see Introduction). In the present work we devised a procedure for obtaining high yields of SLS [about $2 \times 10^{5} \mathrm{HU}(1 \text { culture })^{-1}$ ] by repetitive induction of the same suspension of streptococcal cells with RNA-core. The toxin was purified to apparent electrophoretic homogeneity by a simple two-step process with good recovery $(40 \%)$. Both induction and hydroxylapatite column elution buffers contained the same phosphate concentration, thus allowing direct loading of crude SLS without prior dialysis or lyophilization, which cause significant loss of toxin.

The purified toxin was visualized for the first time by silver-stained SDS-PAGE. By this technique the $M_{\mathrm{r}}$ was estimated as below 4000 , whereas we obtained a value of 40000 by gel filtration on Sephadex G-100 (as was also reported by Hryniewicz et al., 1978) and of 20000 by the same technique in $6 \mathrm{M}$-guanidine. In similar determinations in guanidine or urea, values of 15200 and 22500 were reported by Lai et al. (1978) and Hryniewicz et al. (1978), whereas a value of 18500 was obtained by Calandra \& Oginsky (1975) in sucrose buffer. Bernheimer (1967) reported a value of 20000 , obtained by ultracentrifugation in a sucrose gradient. These data suggest a tendency of SLS to aggregate, as also observed for two membrane-damaging hydrophobic peptide toxins, staphylococcal delta-toxin (Freer \& Arbuthnott, 1983) and bee venom melittin (Talbot et al., 1982).

Purified SLS (fraction F2) had a specific activity of $3 \times 10^{6} \mathrm{HU}$ (mg protein) $)^{-1}$ determined according to the assay system of Lai et al. (1978), a value similar to that reported by these investigators. On the basis of these data SLS is one of the most powerful haemolytic agents known (see Alouf, 1977). Its activity is about 100000 times that of surfactin, saponin, melittin and staphylococcal delta-toxin (Bernheimer, 1972, 1983).

The amino acid composition of purified SLS showed some similarities with that reported by Koyama (1963) and Lai et al. (1978) as regards the proportions or the absence of certain residues. However, interpretation of these data is difficult because of the presence of contaminating protein(s) in RNA-core, also reported in the inducing ribonucleotides used by Koyama (1963) and Lai et al. (1978). A preliminary attempt to sequence purified SLS obtained in this work failed, as did amino terminal determination by Edman degradation, suggesting that this residue might be blocked, as found for staphylococcal delta-toxin (Fitton et al. 1984), or that the peptide moiety of SLS could be cyclic, like various ionophores and membrane-damaging peptides such as gramicidin (Fornili et al., 1984) and Microcystis aeruginosa toxin (Grabow et al., 1982).

Purified SLS was submitted to IEF in an attempt to isolate the peptide moiety and to investigate whether the RNA contaminant protein was associated with the toxin. SLS resolved into six peaks of different pI, two of which, of pI 3.6 and 9.2, were haemolytic. The major haemolytic activity was located in the acidic fraction. This probably corresponds to undissociated RNA-SLS complex, which would therefore appear as a highly negatively charged molecule (as also inferred from the migration of the toxin when submitted to PAGE in nondissociating conditions at $\mathrm{pH} 8.9$ ). The negatively charged repeating polymer backbone of the ribonucleotide core might contribute significantly to the net charge of the toxin. The same acidic haemolytic fraction when refocused in urea split into two components, of pI 4.95 and 9.7, whereas under the same conditions fraction F2 yielded three peaks, of pI 5.1, 6.5 and 9.5, suggesting that the material focusing around $\mathrm{pH} 6 \cdot 0$ was RNA-core contaminating protein(s). The pI 3.6 fraction was free from this material and thus more pure than F2. The haemolytic fraction of pI $9 \cdot 2$ (BHF) is apparently the peptide moiety of SLS isolated for the first time in a haemolytically active state, as discussed below. The apparent $M_{\mathrm{r}}$ of this fraction denatured by heating with SDS was 1800 .

BHF and purified SLS shared common properties as regards haemolytic activity. However, BHF was much more labile than SLS and was substantially stabilized by RNA-core as a 
function of the concentration of this component up to a critical value. Above this value a decrease of BHF stability was observed, suggesting that the effect of RNA-core could not be simply attributable to non-specific protection of $\mathrm{BHF}$ against adsorption to surfaces. The kinetics of the lysis elicited by BHF was similar to that found for SLS except for the longer lag period. This may either be due to the higher lability of the peptide or to carrier involvement in cell-toxin interactions.

SLS-like toxins have been shown to be produced by Treponema hyodysenteriae in the presence of RNA-core, Tween 80 and serum albumin (Knoop, 1981; Lemcke \& Burrows, 1982), by Streptococcus mutans in the presence of Tween 80 (Woltjes et al., 1981) and by Streptococcus agalactiae in the presence of Tween, starch or lipoteichoic acid (Marchlewicz \& Duncan, 1980; Dal \& Monteil, 1983; Tsaihong \& Wennerström, 1983). For the last two organisms RNA-core was inactive as an inducer. A comparative study of these various haemolysins would be of great interest. The demonstration of SLS production in vivo (Duncan, 1983) and the known leucotoxicity of the toxin (Sullivan \& Mandell, 1981) warrants further study of SLS and related toxins and their possible contribution to pathogenicity. The work described here, particularly the isolation of the haemolytic peptide, will enable us to gain a better insight into SLS structure, its cytolytic effects and the biological relation between the peptide and the inducer/stabilizer moiety.

We thank Drs A. M. Gilles, P. Falmagne and A. de Wolff for assistance with protein analysis, Drs C. Geoffrey and C. Jolivet-Reynaud for helpful discussions and Miss L. Cayrol for secretarial assistance.

This work was supported by grants from AGIR and the Caisse Nationale de l'Assurance Maladie des Travailleurs Salariés, which we are pleased to acknowledge.

\section{REFERENCES}

Alouf, J. E. (1977). Cell membranes and cytolytic bacterial toxins. In The Specificity and Action of Animal, Bacterial and Plant Toxins, pp. 219-270. Edited by P. Cuatrecasas. London: Chapman \& Hall.

Alouf, J. E. (1980). Streptococcal toxins (streptolysin $\mathrm{O}$, streptolysin S, erythrogenic toxin). Pharmacology and Therapeutics 11, 661-717.

Alouf, J. E. \& Raynaud, M. (1968). Action de la streptolysine $\mathrm{O}$ sur les membranes cellulaires. I. Fixation sur la membrane érythrocytaire. Annales de l'Institut Pasteur 114, 812-827.

BernHEImer, A. W. (1954). Streptolysins and their inhibitors. In Streptococcal Infections, pp. 19-38. Edited by $M$. McCarty. New York: Columbia University Press.

Bernheimer, A. W. (1967). Physical behavior of streptolysin S. Journal of Bacteriology 93, 2024-2025.

BERnHeImer, A. W. (1972). Hemolysins of streptococci: characterization and effect on biological membranes. In Streptococci and Streptococcal Diseases, pp. 19-31. Edited by L. W. Wannamaker \& J. H. Matsen. New York: Academic Press.

Bernheimer, A. W. (1983). Lipid-specific toxins from bacteria, insects and marine invertebrates. Transactions of the New York Academy of Sciences, series II 41, 25-34.

Bernheimer, A. W. \& Rodbart, M. (1948). The effect of nucleic acid and carbohydrates on the formation of streptolysin S. Journal of Experimental Medicine 88, 149-168.

Calandra, G. B. \& Oginsky, E. L. (1975). Cellular SLS-related hemolysins of group A Streptococcus C203S. Infection and Immunity 12, 13-28.

Dal, M. \& MonteIL, H. (1983). Hemolysin produced by group B Streptococcus agalactiae. FEMS Microbiology Letters 16, 89-94.

Dassy, B. \& Alouf, J. E. (1983). Growth of Streptococcus pyogenes and streptolysin $\mathrm{O}$ production in complex and synthetic media. Journal of General Microbiology 129, 643-651.

DEVENYI, T. (1969). Modified single column procedure of the automatic analysis of amino acids. Acta biochimica et biophysica Academiae scientiarum hungaricae 4, 297-299.

Duncan, J. L. (1983). Streptococcal growth and toxin production in vivo. Infection and Immunity 40, 501505.

Duncan, J. L. \& Buckingham, L. (1981). Effect of streptolysin $\mathrm{S}$ on liposomes. Influence of membrane lipid composition on toxin action. Biochimica et biophysica acta 648, 6-12.

DunCAN, J. L. \& MASON, L. (1976). Characteristics of streptolysin $\mathrm{S}$ hemolysis. Infection and Immunity 14 , 77-82.

Elias, N., Heller, M. \& Ginsburg, I. (1966). Binding of streptolysin $\mathrm{S}$ to red blood cell ghosts and ghost lipids. Israel Journal of Medical Science 2, 302-309.

Fitton, J. E., Hunt, D. F., Marasco, J., Shabanowitz, J., Winston, S. \& Dell, A. (1984). The amino acid sequence of delta haemolysin purified from a canine isolate of Staphylococcus aureus. FEBS Letters 169, 25-29.

Fornili, S. L., Vercauteren, D. P. \& Clementi, E. (1984). Water structure in the gramicidin A transmembrane channel. Biochimica et biophysica acta 771, 151-164.

Freer, J. H. \& Arbuthnott, J. P. (1983). Toxins of Staphylococcus aureus. Pharmacology and Therapeutics 19, 55-106. 
GinsBuRg, I. (1970). In Microbial Toxins, pp. 99-171. Edited by T. C. Montie, S. Kadis \& S. Ajl. New York: Academic Press.

GinsburG, I. \& Harris, T. N. (1963). Oxygen-stable haemolysins of group A streptococci. II. Chromatographic and electrophoretic studies. Journal of Experimental Medicine 118, 913-934.

Grabow, W. O. K., DU Randt, W. C., Prozesky, O. W. \& SCOTT, W. E. (1982). Microcystis aeruginosa toxin: cell toxicity, haemolysis and mutagenicity assays. Applied and Environmental Microbiology 43, 1425-1433.

HERBERT, D. \& TODD, E. W. (1944). The oxygen-stable haemolysin of group A haemolytic streptococci (streptolysin S). British Journal of Experimental Pathology 25, 242-254.

Hryniewicz, W., Gray, E. D., TagG, I., WannaMAKER, L. W., KANCLERSKI, K. \& LAIBLE, N. (1978). Streptolysin S: purification and properties. Zentralblatt für Bakteriologie, Mikrobiologie und Hygiene, Series A, 242, 327-338.

KNOOP, F. C. (1981). Investigation of a hemolysin produced by enteropathogenic Treponema hyodysenteriae. Infection and Immunity 31, 193-198.

KoYama, J. (1963). Biochemical studies on streptolysin $S^{\prime}$. II. Properties of a polypeptide component and its role in the toxin activity. Journal of Biochemistry 54, 146-151.

Koyama, J. \& Egami, F. (1963). Biochemical studies on streptolysin $\mathbf{S}^{\prime}$ formed in the presence of yeast ribonucleic acid. I. The purification and some properties of the toxin. Journal of Biochemistry 53, $147-154$

LAEMMLI, U. K. (1970). Cleavage of structural proteins during the assembly of the head of bacteriophage T4 Nature, London 227, 680-685.

LaI, C. Y., Wang, M. T., De Faria, J. B. \& AkaO, T. (1978). Streptolysin $S$ : improved purification and characterization. Archives of Biochemistry and Biophysics 191, 804-812.
LemcKe, R. M. \& BurRows, M. R. (1982). Studies on a haemolysin produced by Treponema hyodysenteriae. Journal of Medical Microbiology 15, 205-214.

MaRChlewicz, B. A. \& DunCAN, J. L. (1980). Properties of a hemolysin produced by group B streptococci. Infection and Immunity 30, 805-813.

MORRISSEY, J. H. (1981). Silver stain for proteins in polyacrylamide gels: a modified procedure with enhanced uniform sensitivity. Analytical Biochemis$\operatorname{try} \cdot 117,307-310$.

Spackman, D. H., Stein, W. H. \& Moore, S. (1958). Automatic recording apparatus for use in the chromatography of amino acids. Analytical Chemistry 30, 1190-1206

Sullivan, G. W. \& Mandell, G. L. (1981). The role of the neutrophil degranulation in streptococcal leukotoxicity. Infection and Immunity 33, 267-274.

TAKETO, A. \& TAKETO, Y. (1964). Biochemical studies on streptolysin $\mathrm{S}$ formation. II. On the transfer of streptolysin S. Journal of Biochemistry 56, 562-567.

Talbot, J.-C., Lalanne, J., Faucon, J.-F. \& DufourcQ, J. (1982). Effect of the state of association of melittin and phospholipids on their reciprocal binding. Biochimica et biophysica acta 689 , 106-112.

Theodore, T. S. \& Calandra, G. B. (1981). Streptoly$\sin \mathrm{S}$ carrier activity of lipoteichoic acid. In Chemistry and Biological Activities of Bacterial Surface Amphiphiles, pp. 271-278. Edited by G. D. Shockman \& A. J. Wicken. New York: Academic Press.

TSAIHONG, J. C. \& WenNerström, D. E. (1983). Effect of carrier molecules on production and properties of extracellular hemolysin produced by Streptococcus agalactiae. Current Microbiology 9, 333-338.

Woltjes, J., Legdeur-Velthuis, H. \& DE Graaf, J. (1981). Detection and characterization of hemolysin production in Streptococcus mutans. Infection and Immunity 31, 850-855. 